\title{
Phase 1 results of safety and tolerability in a rush oral immunotherapy protocol to multiple foods using Omalizumab
}

Philippe Bégin ${ }^{1}$, Tina Dominguez ${ }^{1}$, Shruti P Wilson ${ }^{1}$, Liane Bacal ${ }^{1}$, Anjuli Mehrotra ${ }^{1}$, Bethany Kausch ${ }^{1}$, Anthony Trela ${ }^{1}$, Morvarid Tavassoli', Elisabeth Hoyte', Gerri O'Riordan', Alanna Blakemore', Scott Seki ${ }^{1}$, Robert G Hamilton ${ }^{2}$ and Kari C Nadeau ${ }^{1 *}$

\begin{abstract}
Background: Up to $30 \%$ of patients with food allergies have clinical reactivity to more than one food allergen. Although there is currently no cure, oral immunotherapy (OIT) is under investigation. Pilot data have shown that omalizumab may hasten the ability to tolerate over $4 \mathrm{~g}$ of food allergen protein.

Objective: To evaluate the safety and dose tolerability of a Phase 1 Single Site OIT protocol using omalizumab to allow for a faster and safe desensitization to multiple foods simultaneously.

Methods: Participants with multiple food allergies received OIT for up to 5 allergens simultaneously with omalizumab (rush mOIT). Omalizumab was administered for 8 weeks prior to and 8 weeks following the initiation of a rush mOIT schedule. Home reactions were recorded with diaries.

Results: Twenty-five (25) participants were enrolled in the protocol (median age 7 years). For each included food, participants had failed an initial double-blind placebo-controlled food challenge at a protein dose of $100 \mathrm{mg}$ or less. After pre-treatment with omalizumab, 19 participants tolerated all 6 steps of the initial escalation day (up to $1250 \mathrm{mg}$ of combined food proteins), requiring minimal or no rescue therapy. The remaining 6 were started on their highest tolerated dose as their initial daily home doses. Participants reported 401 reactions per 7,530 home doses (5.3\%) with a median of 3.2 reactions per 100 doses. Ninety-four percent (94\%) of reactions were mild. There was one severe reaction. Participants reached their maintenance dose of $4,000 \mathrm{mg}$ protein per allergen at a median of 18 weeks.

Conclusion: These phase 1 data demonstrate that rush OIT to multiple foods with 16 weeks of treatment with omalizumab could allow for a fast desensitization in subjects with multiple food allergies. Phase 2 randomized controlled trials are needed to better define safety and efficacy parameters of multi OIT experimental treatments with and without omalizumab.
\end{abstract}

Keyword: Food allergy, Oral immunotherapy (OIT), Specific Oral Tolerance Induction (SOTI), Multiple food allergy, Safety, Efficacy, Omalizumab, Desensitization

\section{Introduction}

Up to $8 \%$ of the pediatric population suffers from food allergy and of those $30 \%$ have clinical reactivity to more than one food allergen [1-3]. The estimated cost of food allergies in the U.S. every year is approximately 25 billion U.S. dollars, with most of the burden ( $\sim 20$ billion) borne

\footnotetext{
* Correspondence: knadeau@stanford.edu

${ }^{1}$ Allergy, Immunology, and Rheumatology Division, Stanford University, 269

Campus Drive, CCSR3215c, Stanford, CA, 94305, USA

Full list of author information is available at the end of the article
}

by families themselves due to time lost from work, changing careers and emergency room visits [4]. Compared to those with single food allergies, multi-sensitized subjects experience a greater decrease in quality of life [5], are more likely to suffer from dietary deficiencies [6] and are less prone to spontaneously outgrow their allergies [7].

Oral, sublingual, and epicutaneous allergen-specific immunotherapies have been proposed as possible methods of desensitization for foods. Several prior studies have 
shown some success in using these approaches for single specific food allergens such as milk [8-15], egg [13,14,16-18], peanut [19-24], and hazelnut [25]. These current types of experimental treatments need to be tested for optimization in safety, efficacy, and length of time [26-34]. Safety is of critical importance at all phases of any protocol (initial dose escalation day, dose escalation, and maintenance phases) and allergic reactions while on OIT remain an important feature in long-term follow-up studies and in determining the overall success of food allergen immunotherapy [35]. However, one major limitation to the clinical application of current protocols is their use in participants with more than one food allergy, which would require multiple sequential rounds of immunotherapy over many years. We have recently reported that up to 5 allergens can be desensitized simultaneously without an increase in reaction rate when compared to single allergen desensitization [36]. However this protocol remained time consuming with a median of 85 weeks to reach maintenance dose (range $=54-156$ ).

The use of IgE immunomodulatory therapies, including monoclonal antibodies and small molecules, has been under investigation in food allergies and has been reviewed recently in the literature [37-45]. Specifically, omalizumab has been shown to increase the threshold for adverse reactions on food challenge by up to 80 fold [41]. After obtaining pharmacodynamic data using basophil assays and free IgE measurements in subjects with food allergies who received standard omalizumab dosing, we found that 8 weeks post standard omalizumab therapy is an optimal time to start oral immunotherapy [46,47]. This concept of rush immunotherapy with omalizumab was previously used in immunotherapy studies involving pollens, milk and peanut with promising results [28,30,48-52]. Combined with food OIT, omalizumab is posited to increase dose tolerability, thus allowing for the possibility of a higher initial starting dose and faster treatment progression.

The objective of this trial was to study the safety and dose tolerability of a phase 1, open-label, rush OIT protocol, which included up to 5 foods simultaneously. The primary endpoint of our investigation was safety (i.e. the occurrence of allergic reactions throughout the course of the study). The secondary endpoints (i.e. tolerability) were i) the time to reach and maintain doses of $300 \mathrm{mg}, 1000 \mathrm{mg}$ and $4000 \mathrm{mg}$ per food allergen protein as well as ii) a 10 fold increase from the baseline reactivity threshold to each of the food allergen proteins.

\section{Methods}

This open-label, phase 1 study was performed in a single center hospital setting, with Institutional Review Board (IRB) and Investigational New Drug (IND) approvals. This project was approved by the IRB committee at Stanford University.

\section{Participant selection}

Participants were eligible for inclusion if they: (1) were older than or equal to 4 years old; had proven sensitivity to at least two food allergens documented by both (2) a skin prick test (with neat extracts from Greer Laboratories, Lenoir, NC) greater than $3 \mathrm{~mm}$ (wheal), and (3) foodspecific IgE greater than $0.35 \mathrm{ku} / \mathrm{L}$ (ImmunoCAP); (4) had clinical reactivity to those food proven by positive allergic reaction in a double-blind placebo-controlled oral food challenge (DBPCFC) as described below; and (5) had signed informed consent. Specific food allergens that were eligible for inclusion in this trial included cow's milk, egg, peanut, nuts, grains and sesame seed. Exclusion criteria included: (1) eosinophilic esophagitis; (2) autoimmune disease; (3) severe cardiac disease; chronic treatment with (4) beta-adrenergic antagonists or (5) steroids; (6) a history of severe anaphylaxis requiring admission to an intensive care unit; (7) frequent allergic or non-allergic urticaria; and (8) poorly controlled asthma (defined as FEV1 below 80 percent of predicted).

DBPCFCs were performed on different days and separated by 72 hours for each qualifying food allergen and for the placebo (oat, or rice flour if allergic to oat). All participants performed spirometry, as appropriate per age, and had continuous pulse-oximetry and vital sign monitoring, every 15 minutes prior to and following increasing doses of placebo or allergenic food protein. DBPCFC doses were increased over 3.5 hours up to a cumulative dose of $182 \mathrm{mg}$ food protein until an objective reaction occurred. Clinical reactivity was based on Bock's criteria (grade 1 or above) [53]. The DBPCFC procedure used was described in a previous publication [36].

DBPCFCs and dose escalations occurred in a hospital with immediate access to a trained physician and study personnel. Given that reactions are expected to occur with OIT, training for the use of and indication for autoinjectable epinephrine was given to all participants and families/guardians at screening, on the initial dose escalation day and every three months during OIT. Our method of epinephrine training was described in detail in a previously [36].

\section{Study medications \\ Food flours/powders}

This study used food flours/powders dispensed through a Food Flour/Powder GMP facility at Stanford (as per FDA guidelines (http://www.fda.gov/downloads/Drugs/ GuidanceComplianceRegulatoryInformation/Guidances/ ucm070273.pdf). A Chemistry and Manufacturing Control (CMC) section for each food allergen powder/flour included assessments for stability, identity, relative sterility, and purity of each of the food powders/flours. The food flours/powders we used include milk powder (Organic Valley, WI), egg powder (Deb El, NJ), peanut flour (Byrd Mill, VA), walnut flour (Carriere Family Farms, CA), 
cashew flour (Digestive Wellness, NY), almond flour (Just Almonds, NV), pecan flour (Green Valley, AZ), hazelnut flour (Holmquish Hazelnut Orchards, WA), wheat flour (Gold Medal, MN), soy flour (Honeyville Grain, Inc., UT), and sesame seed flour (Dispasa USA, Inc., TX). Each dose was weighed out by a trained professional on a professional-grade balance. Flour/powder protein content was calculated according to nutritional information provided by manufacturers and confirmed through protein assays run at Stanford laboratories.

\section{Omalizumab}

Omalizumab (Genentech, CA) was prepared and administered according to the product insert. Doses were determined based on weight and total IgE levels as per Omalizumab Global Dosing schedule as outlined in the online supplement (Additional file 1: Table S1).

\section{Study design}

\section{Pre-treatment with omalizumab}

After enrollment, participants $(n=25)$ were pre-treated with omalizumab for 8 weeks according to the product insert dosing schedule to equilibrate with anti-IgE $\mathrm{mAb}$ (Additional file 1: Table S1). Omalizumab injections were administered at the hospital's Clinical Translational Food Unit (CTFU) under medical supervision and patients were observed for at least one hour after injection.

\section{Initial escalation}

On the $9^{\text {th }}$ week after the $1^{\text {st }}$ injection of omalizumab, the participants underwent rapid oral desensitization to up to five offending food allergens (Figure 1). The OIT regimen was customized to what the participant was found to be allergic to in their baseline DBPCFCs. As many as 5 allergens (in 1:1:1:1:1 proportions) could be included in an OIT treatment plan, provided all selected allergens met the inclusion criteria.

All participants were admitted to the CTFU (clinical trial food unit) and vital signs (heart rate, respiratory rate, temperature, blood pressure and pulse oximetry) were monitored every 15 minutes. Trained clinical staff administered doses of food allergen. Antihistamines, inhaled beta- 2 agonists, prednisolone, and injectable epinephrine were all readily available at the bedside.

On the initial escalation day, dosing began at $5 \mathrm{mg}$ total food allergen protein divided equally between each of the offending food allergens (i.e. $1 \mathrm{mg}$ protein of each allergen if 5 were given) and doses were slowly increased until the participant reached a final dose of $1250 \mathrm{mg}$ protein (i.e. up to $250 \mathrm{mg}$ protein of each offending food allergen if the participant's regimen included 5 allergens). Food allergens were given over a period of 2.5 hours as outlined in Table 1. Participants were monitored for vital signs and physical assessments throughout the dosing process and were observed for an additional 2 hours after receiving the final dose. The highest tolerated dose (i.e. with no clinical reactivity) determined the participant's starting daily home dose (up to a total dose of $1250 \mathrm{mg}$ protein, divided evenly into each of the separate offending food allergens).

\section{Home dosing}

Individual doses were provided containing all of the participant's allergens. Participants were instructed to ingest their dose after a full meal at approximately the same time each day. Each food allergen was given simultaneously in applesauce or pudding (or another medium the participant had shown tolerance to during placebo challenge). They were instructed not to miss their daily dose. Participants and their families were given instructions on how to monitor for reactions at home and record any symptoms in their dosing diary. Research staff kept in close contact with participants and families to investigate and document any adverse events. All families and participants had 24-hour contact information for study personnel in case of an allergic reaction and/or questions at any point during the study. All participants were provided with injectable epinephrine devices, oral antihistamines, and a treatment plan for possible allergic reactions. They were trained on the use of self-injectable

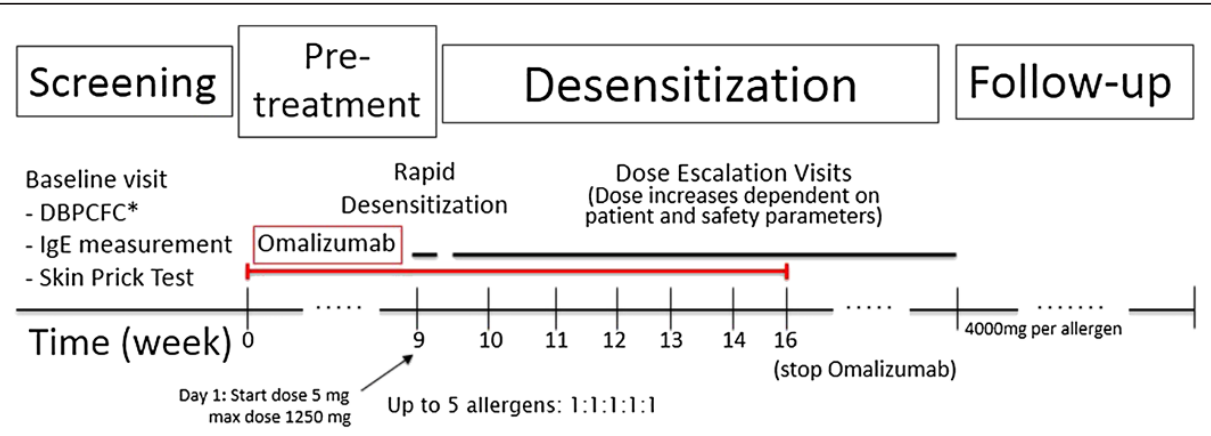

Figure 1 Rush moIT protocol timeline. Amount of maintenance dose depends on number of allergens dosed (4000 mg per allergen). *Double-blind, placebo-controlled food challenges (DBPCFCs). 
Table 1 Rush molT initial escalation day schedule

\begin{tabular}{cc}
\hline Dose in $\mathbf{m g}$ of protein & Dosing interval in minutes \\
\hline 5 & 30 \\
50 & 30 \\
150 & 30 \\
300 & 30 \\
625 & 30 \\
1250 & 120 \\
\hline
\end{tabular}

epinephrine. Participants were instructed to avoid physical exertion 1 hour before and 2 hours after dosing and to contact the on-call service in the event of infection or environmental allergies. The goal of the OIT was to achieve a daily maintenance dose of $4000 \mathrm{mg}$ protein of each allergen (up to 20,000 mg protein cumulative dose for participants taking 5 allergens in their OIT).

\section{Dose escalation}

The participants returned to the CTFU every two weeks for a dose escalation visit with daily home diaries, which detailed any symptoms that occurred and treatments given during the daily home dosing for the prior 2 weeks. Staff reviewed the dose diaries with the participants and their families at each visit. If home daily protein flour/ powder doses had been well tolerated, the dose was increased in the hospital setting according to a predetermined scale as outlined in Table 2. Trained clinicians in the CTFU monitored participants for at least one hour following their new dose. If the new dose was tolerated, it subsequently became their daily dose for the following two weeks; otherwise they continued on their previous dose. Importantly, OIT protocols did not advance according to a fixed calendar, but, rather were individualized according to participants' allergic reactions and safety outcomes.

Table 2 Rush molT dose escalation schedule

\begin{tabular}{ccc}
\hline Dose of protein $(\mathbf{m g})$ & Interval in weeks & $\begin{array}{c}\% \text { of increase } \\
\text { from previous }\end{array}$ \\
\hline $2350 \mathrm{mg}$ & 2 & $88 \%$ \\
$4000 \mathrm{mg}$ & 2 & $70 \%$ \\
$5800 \mathrm{mg}$ & 2 & $45 \%$ \\
$7600 \mathrm{mg}$ & 2 & $50 \%$ \\
$9400 \mathrm{mg}$ & 2 & $30 \%$ \\
$11200 \mathrm{mg}$ & 2 & $20 \%$ \\
$14000 \mathrm{mg}$ & 2 & $25 \%$ \\
$17500 \mathrm{mg}$ & 2 & $25 \%$ \\
$20000 \mathrm{mg}$ & 2 & $14 \%$ \\
\hline
\end{tabular}

\section{Omalizumab discontinuation}

Omalizumab treatment was discontinued 8 weeks after the initial escalation day of food allergens, totaling 16 weeks total of omalizumab treatment.

\section{Allergy testing}

Peanut was the most frequent food allergen determined in the 25 participants (Additional file 1: Tables S2). Specific skin prick test (peanut extract from Greer Laboratories, Lenoir, NC) and serologies were compared at baseline and after a year of therapy. Sera were analyzed for peanutspecific IgE and IgG4 levels at John Hopkins Allergy and Clinical Immunology Reference Laboratory by immunoCAP FEIA (Thermofisher Scientific/Phadia, Kalmazoo, MI). IgE antibody levels $<0.1 \mathrm{kU}_{\mathrm{A}} / \mathrm{L}$ and IgG4 antibody levels $<0.01 \mathrm{kU}_{\mathrm{A}} / \mathrm{L}$ were considered undetectable.

\section{Statistical analysis}

Dose progression was measured as the time to reach: 1) a 10-fold increase from initial cumulative dose eliciting a reaction on DBPCFC to each food allergen; as well as doses of 2) $300 \mathrm{mg}$; 3) $1000 \mathrm{mg}$; and 4) $4000 \mathrm{mg}$ protein per food allergen. Food allergy testing results before and after therapy were compared with the Wilcoxon paired $\mathrm{T}$ test. All analyses were performed using GraphPad PRISM software version 6.0b (GraphPad, LaJolla, CA).

\section{Results \\ Overall}

Of a total of 53 participants screened, 25 met inclusion criteria and were enrolled in the phase 1 protocol. Detailed food allergen diagnoses are available in the online supplement (Additional file 1: Tables S3). Initial baseline clinical characteristics and number of allergens are presented in Table 3.

Over the study period, there were 3 withdrawals because of non-compliance with study medication. Overall, a total of 227 hospital-based dose escalation doses and 7,530 home doses were given (Table 4). Throughout the study, no participant missed more than 3 doses consecutively as recorded per their dose diaries.

\section{Safety}

Rates and nature of dose reactions are depicted in Figure 2 for initial dose escalation day, dose escalations, and home dosing. Most (94\%) allergic reactions were mild and included mainly abdominal pain, pruritus, and local ENT symptoms. Although 13 participants (52\%) experienced some symptom on their initial dose escalation day, 19 (76\%) were able to reach the full $1250 \mathrm{mg}$ of food protein total. With home dosing, 401 of the 7530 doses (5.3\%) triggered reactions with a median reaction rate of 3.2 per 100 doses [0.1-18.5]. Most home reactions occurred in the first months of therapy, with reaction 
Table 3 Subjects baseline characteristics

\begin{tabular}{lc}
\hline Number of subjects & 25 \\
Median age in yrs (range) & $7.4(4.5-15.4)$ \\
Male & $19(76 \%)$ \\
Clinical reaction & \\
$\quad$ Respiratory & $5(20 \%)$ \\
$\quad$ Gastro-intestinal & $13(52 \%)$ \\
$\quad$ Epinephrine & $1(4 \%)$ \\
Number of foods dosed & \\
2 & $7(28 \%)$ \\
3 & $4(16 \%)$ \\
4 & $7(28 \%)$ \\
$\quad 5$ & $7(28 \%)$ \\
Peanut baseline allergy test (if included in mix) & \\
(median and range) & \\
$\quad$ SPT in mm & $13(3.5-26)$ \\
Specific lgE in kUa/L & $31(1-192)$ \\
$\quad$ Lowest amount triggering reaction in & $15.5(1.6-100)$ \\
DBPCFC in mg protein & \\
Highest baseline allergy test (median and range) & \\
SPT in mm & $17(6-29.5)$ \\
Specific lgE in kUa/L & $66(2-256)$ \\
Lowest amount triggering reaction in & $6(0.1-100)$ \\
\hline Total IgE in kuA/L (median and range) & $645(67-1829)$ \\
\hline
\end{tabular}

rates dropping by $70 \%$ after 6 months of therapy, from 11 to 3 reactions per 100 doses $(p<0.0001)$ (Figure 3$)$.

Throughout the trial, there were no serious adverse events. One severe reaction occurred shortly after reaching maintenance phase $(16,000 \mathrm{mg})$ in a participant desensitized to peanut, almond, milk and egg. He presented with wheezing, abdominal pain and throat tightness 30 minutes after his dose, which resolved 5 minutes after the self-injection of epinephrine. The family did not report any obvious triggers such as exercise or viral infection.

\section{Dose progression}

As up-dosing was dependent on tolerance to the current dose, dose progression was treated as a marker of tolerability. Kaplan-Meier curves showing time to reach and maintain a 10-fold increase in threshold dose of index food allergen protein, as well as time to reach a dose of $300 \mathrm{mg}, 1000 \mathrm{mg}$, and $4000 \mathrm{mg}$ per food allergen protein are presented in Figure 4. The median time to reach maintenance dose (4000 mg per allergen) was 18 weeks [7-36 weeks] with all participants able to reach this dose by 9 months. All participants had reached a dose equivalent to a 10 -fold increase of all their allergens by 2 months of therapy.
Table 4 Reaction rates with rush mOIT

\begin{tabular}{lc}
\hline Initial escalation day & 25 \\
\hline Escalations performed & $13(52 \%)$ \\
Reactions & $13(52 \%)$ \\
Mild (Grade 1) & 0 \\
Moderate (Grade 2) & 0 \\
Severe (Grade 3) & 0 \\
Epinephrine use & \\
Dose escalations & 227 \\
Doses administered & $13(5.7 \%)$ \\
Reactions & $13(5.7 \%)$ \\
$\quad$ Mild (Grade 1) & 0 \\
Moderate (Grade 2) & 0 \\
Severe (Grade 3) & $0 \%[0-25]$ \\
Median reaction rate [range] & 0 \\
Epinephrine use & \\
Home dosing & $3.2 \%[0.1-18.5]$ \\
Doses administered & $1(0.01 \%)$ \\
Reactions & 7530 \\
Mild (Grade 1) & $401(5.3 \%)$ \\
Moderate (Grade 2) & $385(5.1 \%)$ \\
Severe (Grade 3) & $15(0.2 \%)$ \\
Epinephrine use & $1(0.01 \%)$ \\
\hline & \\
&
\end{tabular}

\section{Allergy testing}

After 52 weeks of therapy, peanut-specific IgE (PN-IgE) did not change significantly (Figure 5). However, peanutspecific IgG4 (PN-IgG4) levels showed median increases of $8.23 \mathrm{mgA} / \mathrm{L}(\mathrm{p}<0.0001)$ while peanut SPT decreased by a median of $8 \mathrm{~mm}(\mathrm{p}<0.0001)$.

\section{Discussion}

In this phase 1 safety study, we have shown that participants allergic to multiple foods were safely and rapidly desensitized to up to five food allergens simultaneously, using a rush OIT protocol with concomitant treatment with omalizumab. To the best of our knowledge, this is the first study to use omalizumab with OIT to multiple allergens simultaneously. These findings are particularly relevant considering the already high $(\sim 30 \%)$ and likely growing number of food allergic participants who are sensitized to more than one food allergen [3,53-56].

This study was designed as a proof of concept, openlabel phase 1 study, with safety measurements as the primary endpoint. The rate of reactions observed in the rush mOIT group was similar to a group with the same eligibility and demographics undergoing mOIT in a previous study without omalizumab, despite the more rapid desensitization schedule [36]. The goal of adding omali- 
A

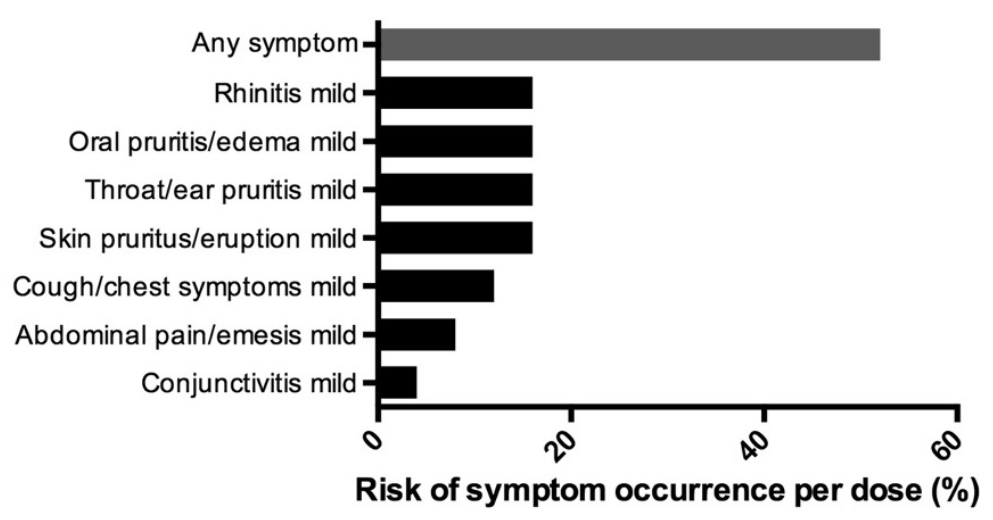

B

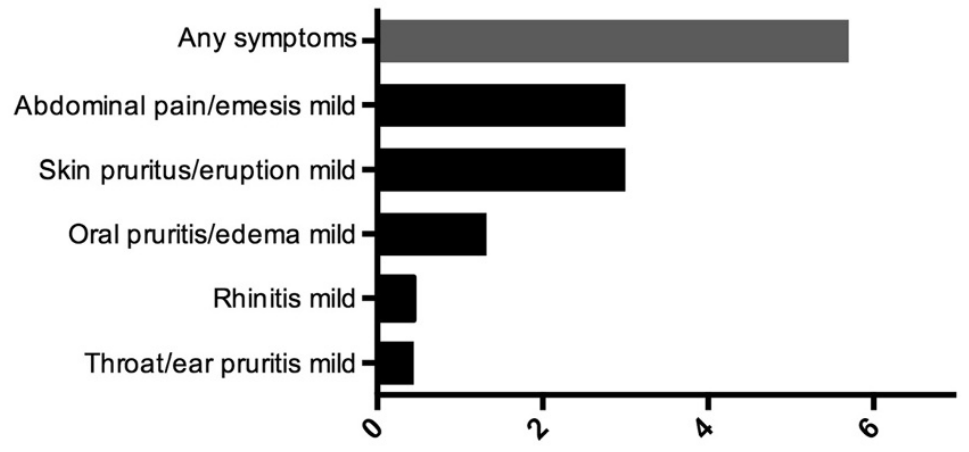

Risk of symptom occurrence per dose (\%)

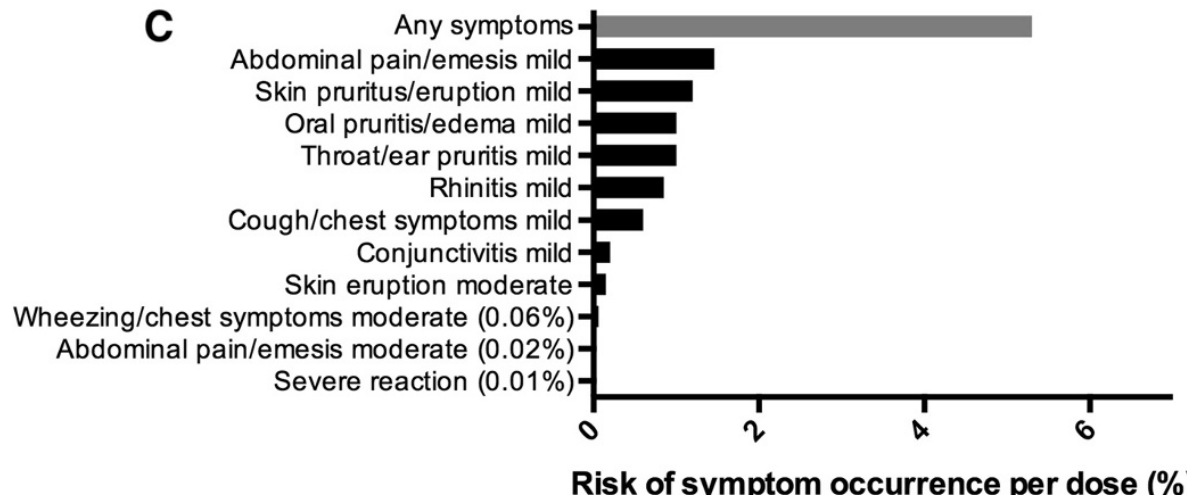

Figure 2 Symptom occurrence during rush mOIT with (A) initial escalation day, (B) dose escalations and (C) home dosing.

zumab in this phase 1 study was primarily to enable rapid desensitization rather than to suppress allergic symptoms during OIT.

As the half-life of omalizumab is 24 days, we further hypothesized that any protective safety effect might wane over time. Participants were observed closely for the development of symptoms, including hives, worsening of eczema, or wheezing after omalizumab discontinuation (at 8 weeks after initial dose escalation), and were instructed to keep a diary of food allergy symptoms throughout the study. Our data show that the home reaction rate actually went down after 24 weeks of therapy from 11 to 3 per 100 doses $(\mathrm{p}<0.0001)$ (Figure 4$)$. This increase in safety could relate to the fact that participants were not up-dosing anymore at that point. However, the only use of epinephrine occurred shortly after the participant had reached the maintenance phase, thus vigilance should not be relaxed at any point. Rescue epinephrine was also required during the maintenance phase of previous rush studies using omalizumab (2 of 2 and 1 of 4 in peanut and milk rush OIT respectively) $[28,52]$.

In addition to the safety data, this phase 1 study of rush mOIT provides initial preliminary evidence of increased dose tolerability. The median time at which participants on rush mOIT reached their maintenance dose $(4000 \mathrm{mg}$ per allergen) was 67 weeks earlier than that reported in a 


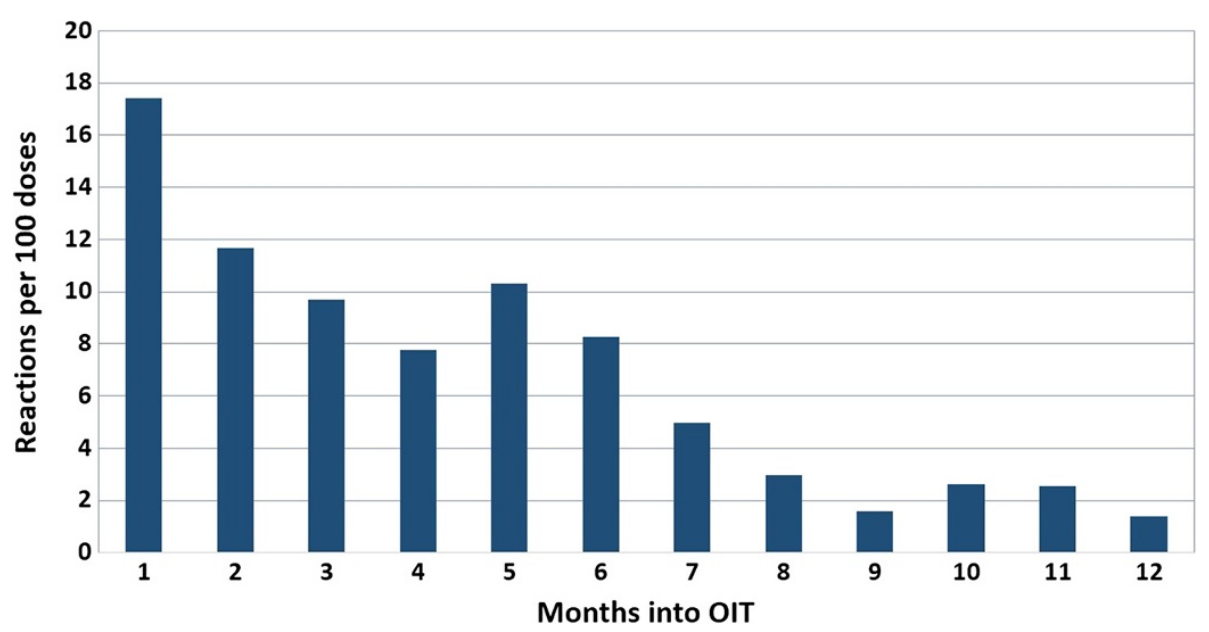

Figure 3 Time distribution of home dosing reactions for the first year of rush mOIT.

previous report on mOIT without omalizumab [36]. This represents a difference of about 34 dose escalations and about 67 additional weeks of enrollment. This might be relevant from a pharmaco-economic perspective. Considering a cost per visit in 2013 of approximately $\$ 160$

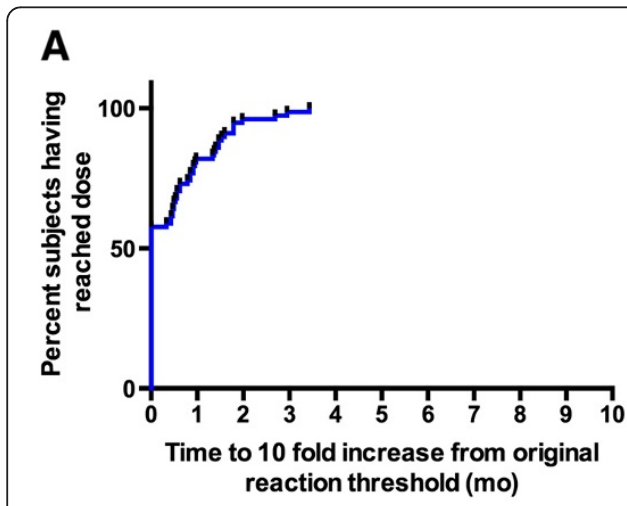

B

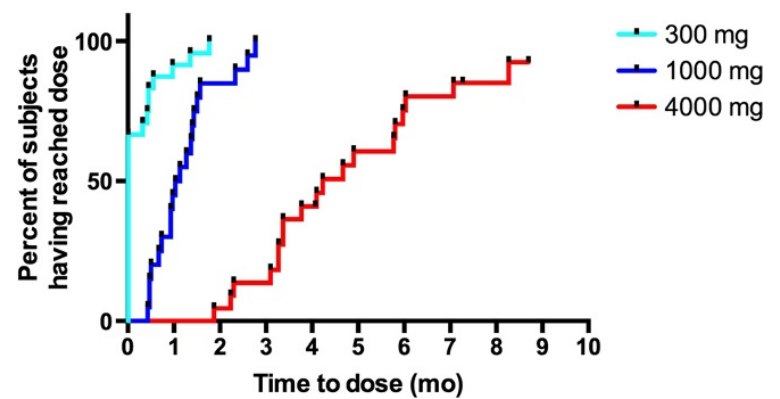

Figure 4 Kaplan-Meier curves showing (A) time to reach the dose corresponding to a 10 fold increase from the threshold at which the patient reacted to index foods on initial DBPCFC (each food reported as a separate event) as well as (B) time to dose of $300 \mathrm{mg}, 1000 \mathrm{mg}$, and $4000 \mathrm{mg}$ protein per each allergen. [approximate cost of an office open food challenge per MediCare or public health insurance in Canada (RAMQ)], those 34 extra visits represent a minimal additional cost of approximately $\$ 5,440$ in 2013 [57]. This could possibly offset the cost of omalizumab at the current time, which varies between $\$ 2,164$ and $\$ 10,824$ for 16 weeks, depending on the patient's weight and total IgE levels. Furthermore, these calculations do not take into account the additional cost and impact of absenteeism from school and work for the participant and his/her parents during these approximate 34 additional visits [4]. However, one should be cautious when comparing these two phase 1 trials as the dose progression schedules were different. A phase 2 study comparing omalizumab to placebo in participants with a similar dosing schedule is needed to truly assess the efficacy gained from the addition of omalizumab to mOIT.

There are limitations to this study. Oral immunotherapy regimens were customized to the participant's food allergies. This has led to some diversity when comparing the composition of specific food allergies between subjects. However, no one food allergen was found to be associated with greater dose tolerability or safety. This is consistent with one of the key long term goals of the study which was to begin to develop customized, patient-based, regimens for oral immunotherapy that could be tested for safety, and dose tolerability.

Importantly, our study showed desensitization but not tolerance. Clinical tolerance is proven by demonstrating sustained unresponsiveness to the food after stopping the maintenance dose for a prolonged period of time. Future phase 2 trials on the use of omalizumab combined with OIT will be useful to see if omalizumab affects this outcome.

Our cohort did not include subjects with high total serum IgE levels as this is sometimes the case for children 

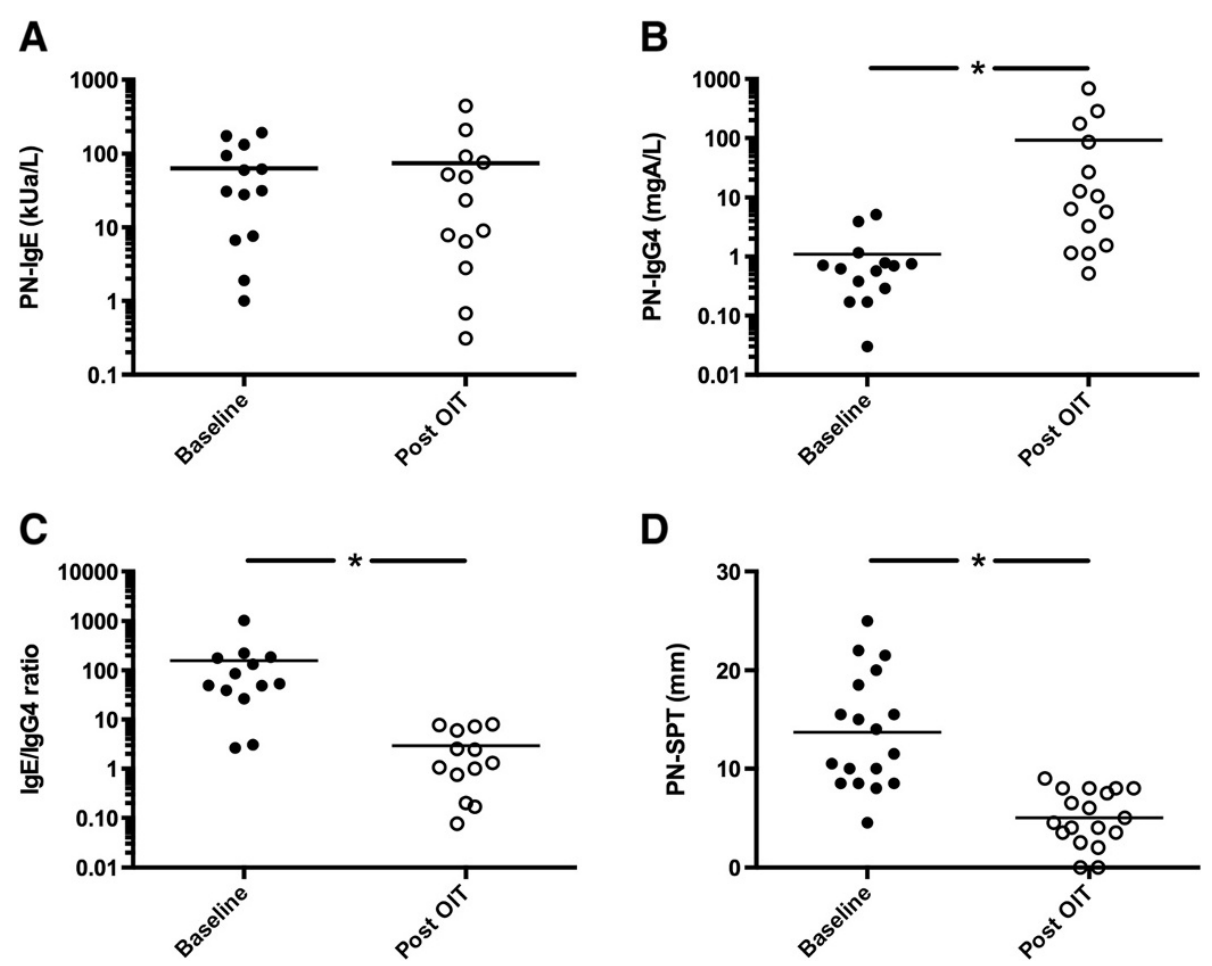

Figure 5 Peanut specific (A) lgE, (B) lgG4, (C) lgE/lgG4 ratio and (D) skin prick test results at baseline and after a year of therapy for participants with proven peanut allergy $(*$ indicates $p<0.0001)$.

with multiple food allergies. Three subjects had total serum IgE slightly greater than $1500 \mathrm{kUa} / \mathrm{L}$ and received the maximum dose of Omalizumab (600 mg every 2 weeks). The optimal dosing for subjects with higher levels would require further study.

Serological analyses were performed for peanut to allow for consistent comparisons between participants, as this was the most frequent allergen. The serologic changes after 52 weeks of therapy were identical to those previously reported in subjects undergoing non-rush OIT (without omalizumab) [36,58].

In conclusion, the data from a single site, phase 1 study demonstrate that a rush OIT protocol to multiple food allergens using adjunct omalizumab can be performed safely in a hospital setting. At this time, rush mOIT is an experimental treatment and should be conducted by trained research personnel with immediate access to emergency equipment. Phase 2, blinded, multicenter trials are needed to continue to determine safety and efficacy parameters of rush mOIT in larger numbers of multi-sensitized participants.

\section{Additional file}

Additional file 1: Table S1. Omalizumab dosing according to weight and total lgE levels. Table S2. Food combinations.

\section{Abbreviations}

CTFU: Clinical trial food unit; DBPCFC: Double-blind placebo-controlled food challenge; EMEA: European Medicines Agency; FDA: Food and drug administration; GMP: Good manufacturing practice; IND: Investigational new drug; IRB: Institutional review board; mOIT: Multiple allergen oral immunotherapy; PN-IgE: Peanut specific Immunoglobulin E; PN-IgG4: Peanut specific immunoglobulin G4; SPT: Skin prick test.

\section{Competing interests}

The authors have no relevant conflict of interest to disclose.

\section{Authors' contributions}

KN conceived and designed the study. PB, TD, LB, TT, BK, AM, AB, SS, GO and MW assessed the patient and acquired clinical data. $P B$ and $K N$ analysed and interpreted the data. MW and $\mathrm{AB}$ performed work on food flours/powders. $\mathrm{RH}$ performed serological analyses. PB, and KN drafted the manuscript. All authors revised the manuscript and approved the final version.

\section{Acknowledgement}

The authors would like to acknowledge Bruce Barnett, PhD and Jelena Berglund, PhD for their review of good manufacturing practices. Funding for this study was provided by the Fund for Food Allergy Research at Stanford. We would like to thank members of the DSMB for their review of the safety data. Philippe Bégin MD, FRCPC was supported by AllerGen NCE Inc. (the Allergy, Gene and Environment Network), a member of the Networks of Centre of Excellence Canada program. We thank the FDA for their review and feedback on the clinical trial. We thank Dr. Sharon Chinthrajah for the reading and editing of the manuscript.

\section{Funding}

Funding for this study was provided by philanthropy and by the Fund for Food Allergy Research at Stanford. 


\section{Author details}

${ }^{1}$ Allergy, Immunology, and Rheumatology Division, Stanford University, 269 Campus Drive, CCSR3215c, Stanford, CA, 94305, USA. ²Dermatology, Allergy and Clinical Immunology Reference Laboratory, Johns Hopkins University School of Medicine, Baltimore, Maryland, USA

Received: 6 December 2013 Accepted: 14 January 2014

Published: 27 February 2014

\section{References}

1. McGowan EC, Keet CA: Prevalence of self-reported food allergy in the National Health and Nutrition Examination Survey (NHANES) 2007-2010. J Allergy Clin Immunol 2013, 132(5):1216-9.

2. Soller L, Ben-Shoshan M, Harrington DW, Fragapane J, Joseph L, St Pierre $Y$ Godefroy SB, La Vieille S, Elliott SJ, Clarke AE: Overall prevalence of selfreported food allergy in Canada. J Allergy Clin Immunol 2012, 130(4):986-988.

3. Gupta RS, Springston EE, Warrier MR, Smith B, Kumar R, Pongracic J, Holl JL: The prevalence, severity, and distribution of childhood food allergy in the United States. Pediatrics 2011, 128(1):e9-e17.

4. Gupta R, Holdford D, Bilaver L, Dyer A, Holl JL, Meltzer D: The economic impact of childhood food allergy in the United States. JAMA Pediatr 2013, 137(11)

5. Sicherer SH, Noone SA, Munoz-Furlong A: The impact of childhood food allergy on quality of life. Ann Allergy Asthma Immunol 2001, 87(6):461-464.

6. Christie L, Hine RJ, Parker JG, Burks W: Food allergies in children affect nutrient intake and growth. J Am Diet Assoc 2002, 102(11):1648-1651.

7. Savage JH, Matsui EC, Skripak JM, Wood RA: The natural history of egg allergy. J Allergy Clin Immunol 2007, 120(6):1413-1417.

8. Skripak JM, Nash SD, Rowley H, Brereton NH, Oh S, Hamilton RG, Matsui EC, Burks AW, Wood RA: A randomized, double-blind, placebo-controlled study of milk oral immunotherapy for cow's milk allergy. J Allergy Clin Immunol 2008, 122(6):1154-1160

9. Pajno GB, Caminiti L, Ruggeri P, De Luca R, Vita D, La Rosa M, Passalacqua G Oral immunotherapy for cow's milk allergy with a weekly up-dosing regimen: a randomized single-blind controlled study. Ann Allergy Asthma Immunol 2010, 105(5):376-381.

10. de Boissieu D, Dupont C: Sublingual immunotherapy for cow's milk protein allergy: a preliminary report. Allergy 2006, 61(10):1238-1239.

11. Longo G, Barbi E, Berti I, Meneghetti R, Pittalis A, Ronfani L, Ventura A Specific oral tolerance induction in children with very severe cow's milk-induced reactions. J Allergy Clin Immunol 2008, 121(2):343-347.

12. Meglio P, Bartone E, Plantamura M, Arabito E, Giampietro PG: A protocol for oral desensitization in children with IgE-mediated cow's milk allergy. Allergy 2004, 59(9):980-987.

13. Fisher HR, du Toit G, Lack G: Specific oral tolerance induction in food allergic children: is oral desensitisation more effective than allergen avoidance?: a meta-analysis of published RCTs. Arch Dis Child 2011, 96(3):259-264.

14. Staden U, Rolinck-Werninghaus C, Brewe F, Wahn U, Niggemann B, Beyer K: Specific oral tolerance induction in food allergy in children: efficacy and clinical patterns of reaction. Allergy 2007, 62(11):1261-1269.

15. Dupont C, Kalach N, Soulaines P, Legoue-Morillon S, Piloquet H, Benhamou PH: Cow's milk epicutaneous immunotherapy in children: a pilot trial of safety acceptability, and impact on allergic reactivity. J Allergy Clin Immunol 2010, 125(5):1165-1167.

16. Dello lacono I, Tripodi S, Calvani M, Panetta V, Verga MC, Miceli SS: Specific oral tolerance induction with raw hen's egg in children with very severe egg allergy: a randomized controlled trial. Pediatr Allergy Immunol 2013, 24(1):66-74.

17. Burks AW, Jones SM, Wood RA, Fleischer DM, Sicherer SH, Lindblad RW, Stablein D, Henning AK, Vickery BP, Liu AH, Scurlock AM, Shreffler WG, Plaut M, Sampson HA; Consortium of Food Allergy Research (CoFAR): Oral immunotherapy for treatment of egg allergy in children. N Engl J Med 2012, 367(3):233-243.

18. Garcia Rodriguez R, Urra JM, Feo-Brito F, Galindo PA, Borja J, Gomez E, Lara P, Guerra F: Oral rush desensitization to egg: efficacy and safety. Clin Exp Allergy 2011, 41(9):1289-1296.

19. Hofmann AM, Scurlock AM, Jones SM, Palmer KP, Lokhnygina Y, Steele PH, Kamilaris J, Burks AW: Safety of a peanut oral immunotherapy protocol in children with peanut allergy. J Allergy Clin Immunol 2009, 124(2):286-291. e1-6.

20. Blumchen $\mathrm{K}$, Ulbricht $\mathrm{H}$, Staden U, Dobberstein K, Beschorner J, de Oliveira LC, Shreffler WG, Sampson HA, Niggemann B, Wahn U, Beyer K: Oral peanut immunotherapy in children with peanut anaphylaxis.

J Allergy Clin Immunol 2010, 126(1):83-91. e1.

21. Clark AT, Islam S, King Y, Deighton J, Anagnostou K, Ewan PW: Successful oral tolerance induction in severe peanut allergy. Allergy 2009, 64(8):1218-1220.

22. Jones SM, Pons L, Roberts JL, Scurlock AM, Perry TT, Kulis M, Shreffler WG, Steele P, Henry KA, Adair M, Francis JM, Durham S, Vickery BP, Zhong X, Burks AW: Clinical efficacy and immune regulation with peanut oral immunotherapy. J Allergy Clin Immunol 2009, 124(2):292-300. e1-97.

23. Yu GP, Weldon B, Neale-May S, Nadeau KC: The safety of peanut oral immunotherapy in peanut-allergic subjects in a single-center trial. Int Arch Allergy Immunol 2012, 159(2):179-182.

24. Fleischer DM, Burks AW, Vickery BP, Scurlock AM, Wood RA, Jones SM, Sicherer SH, Liu AH, Stablein D, Henning AK, Mayer L, Lindblad R, Plaut M, Sampson HA; Consortium of Food Allergy Research (COFAR): Sublingual immunotherapy for peanut allergy: a randomized, double-blind, placebo-controlled multicenter trial. J Allergy Clin Immunol 2013, 131(1):119-127. e1-7.

25. Enrique E, Pineda F, Malek T, Bartra J, Basagana M, Tella R, Castelló JV, Alonso R, de Mateo JA, Cerdá-Trias T, San Miguel-Moncín Mdel M, Monzón S, García M, Palacios R, Cisteró-Bahíma A: Sublingual immunotherapy for hazelnut food allergy: a randomized, double-blind, placebo-controlled study with a standardized hazelnut extract. J Allergy Clin Immunol 2005, 116(5):1073-1079.

26. Gomez E, Mayorga C, Gomez F, Blazquez AB, Diaz-Perales A, Blanca M, Torres MJ: Food allergy: management, diagnosis and treatment strategies. Immunotherapy 2013, 5(7):755-768.

27. Sabato V, Faber M, Van Gasse A, Hagendorens MM, Leysen J, Bridts CH, De Clerck LS, Ebo DG: State of the art and perspectives in food allergy (part II): therapy. Curr Pharm Des 2013. EPub May 172013.

28. Nadeau KC, Kohli A, lyengar S, DeKruyff RH, Umetsu DT: Oral immunotherapy and anti-lgE antibody-adjunctive treatment for food allergy. Immunol Allergy Clin North Am 2012, 32(1):111-133.

29. Yang YH, Chiang BL: Novel approaches to food allergy. Clin Rev Allergy Immunol 2013. EPub Jan 182013

30. Khoriaty $E_{1}$ Umetsu DT: Oral immunotherapy for food allergy: towards a new horizon. Allergy Asthma Immunol Res 2013, 5(1):3-15.

31. Kim EH, Burks W: Managing food allergy in childhood. Curr Opin Pediatr 2012, 24(5):615-620.

32. Nowak-Wegrzyn A, Sampson HA: Future therapies for food allergies. J Allergy Clin Immunol 2011, 127(3):558-573. quiz 74-5

33. Virkud $\mathrm{V}$, Vickery BP: Advances in immunotherapy for food allergy. Discov Med 2012, 14(76):159-165.

34. Nurmatov U, Venderbosch I, Devereux G, Simons FE, Sheikh A: Allergen-specific oral immunotherapy for peanut allergy. Cochrane Database Syst Rev 2012, 9: CD009014.

35. Keet CA, Frischmeyer-Guerrerio PA, Thyagarajan A, Schroeder J, Hamilton RG Boden S, Steele P, Driggers S, Burks AW, Wood RA: The safety and efficacy of sublingual and oral immunotherapy for milk allergy. J Allergy Clin Immunol 2012, 129(2):448-455. e1-5

36. Bégin P, Wintheroth L, Dominguez T, Wilson SP, Bacal L, Mehrotra A, et al: Safety and feasibility of oral immunotherapy to multiple allergens for food allergy. Allergy Asthma Clin Immunol 2014, 10(1):1.

37. Leung DY, Sampson HA, Yunginger JW, Burks AW Jr, Schneider LC, Wortel CH Davis FM, Hyun JD, Shanahan WR Jr, Avon Longitudinal Study of Parents and Children Study Team: Effect of anti-lgE therapy in patients with peanut allergy. N Engl J Med 2003, 348(11):986-993.

38. Sampson HA, Leung DY, Burks AW, Lack G, Bahna SL, Jones SM, Wong DA A phase II, randomized, doubleblind, parallelgroup, placebocontrolled oral food challenge trial of Xolair (omalizumab) in peanut allergy. J Allergy Clin Immunol 2011, 127(5):1309-1310. e1.

39. lyengar SR, Hoyte EG, Loza A, Bonaccorso S, Chiang D, Umetsu DT, Nadeau KC: Immunologic effects of omalizumab in children with severe refractory atopic dermatitis: a randomized, placebo-controlled clinical trial. Int Arch Allergy Immunol 2013, 162:89-93.

40. Bedoret D, Singh AK, Shaw V, Hoyte EG, Hamilton R, DeKruyff RH, Schneider LC, Nadeau KC, Umetsu DT: Changes in antigen-specific T-cell number and function during oral desensitization in cow's milk allergy enabled with omalizumab. Mucosal Immunol 2012, 5(3):267-276.

41. Savage JH, Courneya JP, Sterba PM, Macglashan DW, Saini SS, Wood RA Kinetics of mast cell, basophil, and oral food challenge responses in omalizumab-treated adults with peanut allergy. J Allergy Clin Immuno 2012, 130(5):1123-1129. e2. 
42. MacGlashan DW Jr, Savage JH, Wood RA, Saini SS: Suppression of the basophil response to allergen during treatment with omalizumab is dependent on 2 competing factors. J Allergy Clin Immunol 2012, 130(5):1130-1135. e5.

43. Babu KS, Polosa R, Morjaria JB: Anti-lgE-emerging opportunities for Omalizumab. Expert Opin Biol Ther 2013, 13(5):765-777.

44. Lieberman JA, Chehade M: Use of omalizumab in the treatment of food allergy and anaphylaxis. Curr Allergy Asthma Rep 2013, 13(1):78-84.

45. Patil SP, Wang J, Song Y, Noone S, Yang N, Wallenstein S, Sampson HA, Li XM: Clinical safety of food allergy herbal formula-2 (FAHF-2) and inhibitory effect on basophils from patients with Food allergy: extended phase I study. J Allergy Clin Immunol 2011, 128(6):1259-1265. e2.

46. Gernez Y, Tirouvanziam R, Yu G, Ghosn EE, Reshamwala N, Nguyen T, Tsai M, Galli SJ, Herzenberg LA, Nadeau KC: Basophil CD203c levels are increased at baseline and can be used to monitor omalizumab treatment in subjects with nut allergy. Int Arch Allergy Immunol 2011, 154(4):318-327.

47. Yu GP, Tuano KS, Hamilton RG, Nadeau KC: Omalizumab in peanut-allergic patients reduces free lgE anti-peanut and skin prick test to peanut. J Allergy Clin Immunol 2010, 125(2 Supp 1):AB22.

48. Casale TB, Busse WW, Kline JN, Ballas ZK, Moss MH, Townley RG, Mokhtarani M, Seyfert-Margolis V, Asare A, Bateman K, Deniz Y, Immune Tolerance Network Group: Omalizumab pretreatment decreases acute reactions after rush immunotherapy for ragweed-induced seasonal allergic rhinitis. J Allergy Clin Immunol 2006, 117(1):134-140.

49. Nadeau KC, Schneider LC, Hoyte L, Borras I, Umetsu DT: Rapid oral desensitization in combination with omalizumab therapy in patients with cow's milk allergy. J Allergy Clin Immunol 2011, 127(6):1622-1624.

50. Klunker S, Saggar LR, Seyfert-Margolis V, Asare AL, Casale TB, Durham SR, Francis JN, Immune Tolerance Network Group: Combination treatment with omalizumab and rush immunotherapy for ragweed-induced allergic rhinitis: Inhibition of IgE-facilitated allergen binding. J Allergy Clin Immunol 2007, 120(3):688-695.

51. Parks KW, Casale TB: Anti-immunoglobulin E monoclonal antibody administered with immunotherapy. Allergy Asthma Proc 2006, 27(2 Suppl 1):S33-S36.

52. Schneider LC, Rachid R, Lebovidge J, Blood E, Mittal M, Umetsu DT: A pilot study of omalizumab to facilitate rapid oral desensitization in high-risk peanut-allergic patients. J Allergy Clin Immunol 2013, 132(6):1368-1374.

53. Bock SA, Sampson HA, Atkins FM, Zeiger RS, Lehrer S, Sachs M, Bush RK, Metcalfe DD: Double-blind, placebo-controlled food challenge (DBPCFC) as an office procedure: a manual. J Allergy Clin Immunol 1988, 82(6):986-997.

54. Wang J, Visness CM, Sampson HA: Food allergen sensitization in inner-city children with asthma. J Allergy Clin Immunol 2005, 115(5):1076-1080.

55. Wang J: Management of the patient with multiple food allergies. Curr Allergy Asthma Rep 2010, 10(4):271-277.

56. Park JH, Ahn SS, Sicherer SH: Prevalence of allergy to multiple versus single foods in a pediatric food allergy referral practice. J Allergy Clin Immunol 2010, 125:AB216.

57. Food Allergy in Children and Young People: Diagnosis and Assessment of Food Allergy in Children and Young People in Primary Care and Community Settings. London: National Institute for Health and Clinical Excellence: Guidance; 2011.

58. Varshney P, Jones SM, Scurlock AM, Perry $\Pi$, Kemper A, Steele P, Hiegel A, Kamilaris J, Carlisle S, Yue X, Kulis M, Pons L, Vickery B, Burks AW: A randomized controlled study of peanut oral immunotherapy: clinical desensitization and modulation of the allergic response. J Allergy Clin Immunol 2011, 127(3):654-660.

doi:10.1186/1710-1492-10-7

Cite this article as: Bégin et al:: Phase 1 results of safety and tolerability in a rush oral immunotherapy protocol to multiple foods using Omalizumab. Allergy, Asthma \& Clinical Immunology 2014 10:7.

\section{Submit your next manuscript to BioMed Central and take full advantage of:}

- Convenient online submission

- Thorough peer review

- No space constraints or color figure charges

- Immediate publication on acceptance

- Inclusion in PubMed, CAS, Scopus and Google Scholar

- Research which is freely available for redistribution

Submit your manuscript at www.biomedcentral.com/submit 